\title{
PENGARUH PROFITABILITAS, LIKUIDITAS, DAN STRUKTUR AKTIVA TERHADAP STRUKTUR MODAL PADA PERUSAHAAN MANUFAKTUR DI BEI PERIODE 2012 DAN 2013
}

\author{
Yuda Dwi Saputra dan Desmintari \\ yudadwi.saputra@yahoo.com,desmintari@yahoo.com \\ Fakultas Ekonomi UPN "Veteran" Jakarta \\ Jl. R.S. Fatmawati Pondok Labu, Jakarta Selatan - 12450
}

\section{ABSTRACT}

This objective of this research is to test the effect of Profitability,Liquidity and Structure Assets on Capital Structure. The independent variable in this study was Profitability, Liquidity and Structure Assets, while the dependent variable in this study is the Capital Structure. The population of this research is 139 manufacturing companies listed on the Indonesia Stock Exchange 2012 and 2013 period. The data were obtained from published financial statements of the company. Through purposive sampling technique obtained a total sample of 50 companies. The analysis technique used is multiple linear regression using IBM SPSS (Statistical Product and Service Solutions) version 21.0. The results showed simultaneous Profitability, Liquidity and Structure Assets significant effect on the Capital Structure. While partially variables that doesn't significantly influence the profitability and Structure Assets of Capital Structure, while variable Liquidity significantly influence the Capital Structure.

Keywords : Capital Structure, Profitability, Liquidity and Structure Assets.

\section{PENDAHULUAN}

\section{Latar Belakang Penelitian}

Saat ini persaingan global di Indonesia banyak memberikan perubahan besar dalam perekonomian nasional sehingga mengakibatkan ketatnya persaingan dalam dunia bisnis. Hal ini terlihat dari para pelaku ekonomi baik domestik maupun asing yang melakukan aktifitas usahanya di Indonesia. Dalam menghadapi persaingan tersebut, perusahaan dituntut untuk mempunyai keunggulan bersaing dalam hal produk yang dihasilkan, sumber daya manusianya itu sendiri serta teknologi yang digunakan. Upaya untuk mewujudkan kondisi tersebut dengan profitabilitas yang baik dan dengan tingkat risiko yang diketahui oleh manajer keuangan perusahaan dalam menetapkan struktur modal perusahaan yang diharapkan dapat meningkatkan keuntungan suatu perusahaan dalam menghadapi persaingan bisnis di Indonesia.

Dalam pengambilan keputusan pendanaan yang akan diambil perusahaan untuk membiayai kegiatan usahanya, dan memilih alternatif investasi yang tepat dengan menggunakan modal yang dimiliki oleh perusahaan tersebut. Kombinasi yang tepat dalam pemilihan modal yang dipilih akan mampu menghasilkan struktur modal yang 
optimal yang mampu menjadi pondasi kuat bagi perusahaan untuk menjalankan aktifitas produksinya, serta dapat mendatangkan keuntungan optimal bagi perusahaan dan pemegang sahamnya. Yang dimaksud dengan struktur modal yang optimal adalah struktur modal yang mengoptimalkan keseimbangan antara risiko dan pengembalian sehingga memaksimumkan harga saham (Sari dan A. Mulyo Haryanto, 2013).

Semakin terbukanya akses sumber dana bagi perusahaan, selain mampu menciptakan kemudahan juga menciptakan konsekuensi serta dampak finansial yang berbeda pula. Oleh karena itu seorang manajer keuangan dalam mengambil keputusan pendanaannya harus mempertimbangkan secara cermat baik manfaat maupun biaya dari sumber dana yang akan dipilih. Kebijakan struktur modal melibatkan adanya suatu pertukaran antara risiko dan pengembalian yaitu penggunaan lebih banyak utang akan meningkatkan risiko yang ditanggung oleh pemegang saham. Namun, penggunaan utang yang lebih besar biasanya akan menyebabkan terjadinya ekspektasi tingkat pengembalian atas ekuitas yang lebih tinggi.

Likuiditas perusahaan adalah kekuatan perusahaan dalam melunasi kewajibannya yang jatuh tempo dalam jangka waktu pendek. Jika perusahaan banyak menggunakan aktiva lancar berarti perusahaan tersebut dapat menghasilkan aliran kas untuk membiayai aktivitas operasi dan investasi perusahaan. Aktiva lancar yang semakin besar menunjukan bahwa perusahaan berhasil melunasi hutang jangka pendek nya, sehingga hutang jangka pendek berkurang dan berakibat menurunnya proporsi hutang dalam struktur modal.

Struktur aktiva mencerminkan dua komponen aktiva secara garis besar dalam komposisinya yaitu aktiva lancar dan aktiva tetap. Aktiva lancar adalah uang kas dan aktiva-aktiva lain yang dapat direalisasikan menjadi uang kas atau dijual atau dikonsumsi dalam suatu periode akuntansi yang normal. Sedangkan aktiva tetap adalah aktiva berwujud yang diperoleh dalam bentuk siap pakai atau dibangun lebih dahulu yang digunakan dalam operasi perusahaan, tidak dimasukan untuk dijual dalam rangka kegiatan normal perusahaan dan mempunyai masa.

Dari fenomena diatas membuat penulis tertarik untuk meneliti apa yang menyebabkan tidak terjadi perubahan, kenaikan maupun penurunan terhadap DER-nya. Berdasarkan uraian diatas maka penelitian ini berjudul "Pengaruh Profitabilitas, Likuiditas, Dan Struktur Aktiva Terhadap Struktur Modal Pada Perusahaan Manufaktur Di Bei Periode 2012 Dan 2013".

\section{Perumusan Masalah}

Berdasarkan latar belakang yang telah di kemukakan diatas, maka yang menjadi pokok permasalahan dalam penelitian ini:

a. Apakah profitabilitas, likuiditas dan struktur aktiva berpengaruh secara simultan terhadap struktur modal pada perusahaan manufaktur di BEI periode 2012 dan 2013? 
b. Apakah profitabilitas berpengaruh secara parsial terhadap struktur modal pada perusahaan manufaktur di BEI periode 2012 dan 2013?

c. Apakah likuiditas berpengaruh secara parsial terhadap struktur modal pada perusahaan manufaktur di BEI periode 2012 dan 2013?

d. Apakah struktur aktiva berpengaruh secara parsial terhadap struktur modal pada perusahaan manufaktur di BEI periode 2012 dan 2013?

\section{Tujuan Penelitian}

Sesuai dengan perumusan masalah, maka tujuan penelitian ini adalah:
a. Untuk mengetahui adanya pengaruh profitabilitas, likuiditas

\section{Kerangka penelitian}

dan struktur aktiva secara simultan terhadap struktur modal pada perusahaan manufaktur di BEI periode 2012 dan 2013.

b. Untuk mengetahui adanya pengaruh profitabilitas secara parsial terhadap struktur modal pada perusahaan manufaktur di BEI periode 2012 dan 2013.

c. Untuk mengetahui adanya pengaruh likuiditas secara parsial terhadap struktur modal pada perusahaan manufaktur di BEI periode 2012 dan 2013.

d. Untuk mengetahui adanya pengaruh struktur aktiva secara parsial terhadap struktur modal pada perusahaan manufaktur di BEI periode 2012 dan 2013.

Gambar 1 Kerangka Pemikiran

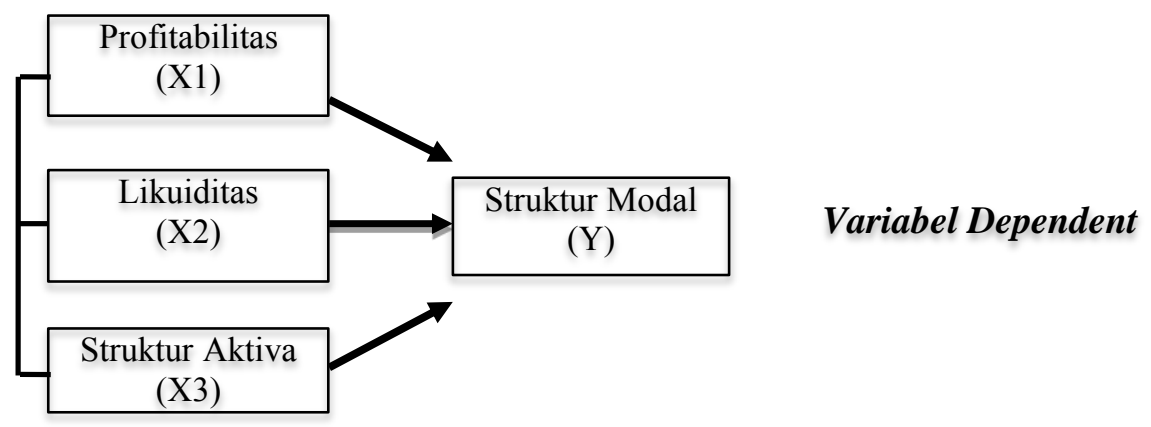

\section{Tinjauan Pustaka}

Pengembangan Hipotesis

\section{Tinjauan Pustaka}

Menurut Harjito, D Agus dan Martono (2011:4), manajemen keuangan atau sering disebut pembelanjaan adalah "segala aktivitas perusahaan yang berhubungan dengan bagaimana memperoleh dana, menggunakan dana, dan mengelola aset sesuai tujuan perusahaan secara dan menyeluruh dengan kata lain manajemen keuangan merupakan manajemen (pengelolaan) mengenai bagaimana memperoleh, mendanai dan mengelola aset untuk mencapai tujuan perusahaan".

Menurut Sitanggang (2012:1), fungsi manajemen keuangan antara lain:

a. Keputusan Investasi (Investment Decision) 
Keputusan investasi tidak terlepas dari komposisi harta perusahaan dalam mendukung kegiatan perusahaan. Keputusan investasi dapat dilihat dari dua sisi yaitu sisi perusahaan emiten yaitu usaha untuk menetapkan komposisi aset yang digunakan untuk kegiatan perusahaan dan dari sisi pemilik modal (investor) yaitu pihak yang mendanai perusahaan baik sebagai kewajiban/utang perusahaan maupun sebagai penyertaan perusahaan.

b. Keputusan (Financing Decision)

Keputusan pembiayaan dapat digunakan untuk menunjukkan dari mana sumber atau asal dana yang membiayai asset perusahaan. Fungsi ini meliputi penentuan kompisisi sumber pembiayaan perusahaan (financing mix) yang ada pada sisi pasiva neraca perusahaan. Berbagai alternatif yang dipilih dapat bersumber dari utang jangka pendek, utang jangka panjang atau ekuitas. Pengambilan keputusan tidak terlepas dari tujuan dan kendala yang di hadapi perusahaan.

c. Keputusan Kebijakan Dividen (Dividen Policy Decision)

Besarnya bagian laba yang ditahan sebagai sumber pembiayaan internal perusahaan merupakan keputusan kebijakan dividen. Apabila sebagian laba bersih ditahan pada perusahaan, berarti adanya komitmen manajemen kepada para pemegang saham bahwa manajemen masih mampu menjanjikan kepada para pemegang saham tingkat hasil yang sesuai dengan yang diminta atau dipersyaratkan oleh para pemegang saham perusahaan.

$\begin{array}{clr}\text { Tujuan } & \text { dari } & \text { manajemen } \\ \text { keuangan } & \text { adalah } & \text { untuk }\end{array}$ memaksimumkan nilai perusahaan. Menurut Sitanggang (2012:6), tujuan dari manajemen keuangan adalah untuk memaksimumkan nilai perusahaan atau memaksimumkan kesejahteraan pemilik modal (to maximize value of firm or to maximize welfare of stockholders) yang dapat diukur dari harga saham di bursa (stock price) bagi perusahaan yang sudah go public, sementara bagi perusahaan yang belum go public (tidak ada harga saham) dapat didekati (proxy) dari tingkat hasil modal sendiri yang dicapai secara berkelanjutan (prediksi jangka panjang). Tujuan demikian berbeda dengan memaksimumkan keuntungan perusahaan (maximize profit), yang tidak memperhatikan nilai waktu dari uang (time value) dan juga tentang risiko atau ketidak pastian (risk/uncertainty).

Sitanggang (2013:27) Struktur keuangan menggambarkan bauran pembiayaan aktiva perusahaan dengan memperhitungkan seluruh sumber pembiayaan utang baik utang jangka pendek maupun utang jangka panjang serta modal sendiri.

Menurut Harjito, D Agus dan Martono (2011:256) ialah perbandingan atau imbangan pendanaan jangka panjang perusahaan yang ditunjukan oleh perbandingan 
hutang jangka panjang terhadap modal sendiri. Pemenuhan kebutuhan dana perusahaan dari sumber modal sendiri berasal dari modal saham, laba ditahan, dan cadangan.

Menurut Harjito, D Agus dan Martono (2011:10) teori Struktur Modal ialah perimbangan antara hutang jangka panjang dengan modal sendiri. Teori mengenai struktur modal pertama kali dikenalkan oleh Franco Modigliani dan Merton Miller (biasa disingkat MM) tahun 1958.

\section{Pengembangan Hipotesis}

Pengaruh Profitabilitas, Likuiditas dan Struktur Aktiva Terhadap Struktur Modal

Sesuai dengan pecking order theory Peningkatan profitabilitas akan meningkatkan laba ditahan, yang mempunyai preferensi pendanaan pertama dengan dana internal berupa laba ditahan, sehingga komponen modal sendiri semakin meningkat dan perusahaan yang mempunyai likuiditas yang tinggi akan cenderung tidak menggunakan pembiayaan dari hutang, hal ini disebabkan perusahaan dengan likuiditas yang tinggi mempunyai dana internal yang besar, sehingga perusahaan tersebut akan lebih menggunakan dana internalnya terlebih dahulu untuk membiayai investasinya sebelum menggunakan pembiayaan eksternal melalui hutang, dinyatakan pula pada struktur aktiva yang besar berarti perusahaan memiliki rasio hutang yang besar.

Sari dan A. Mulyo Haryanto (2013) menyatakan bahwa semua variabel bebas (profitabilitas, likuiditas dan struktur aktiva) secara bersama-sama berpengaruh secara signifikan terhadap variabel struktur modal.

Hal ini sesuai dengan penelitian yang dilakukan oleh Sari dan A. Mulyo Haryanto (2013). Berdasarkan uraian diatas dapat ditarik hipotesis sebagai berikut:

$\mathrm{H}_{1}$ : Profitabilitas, Likuiditas dan Struktur Aktiva secara simultan berpengaruh terhadap struktur modal.

\section{Pengaruh Profitabilitas Terhadap Struktur Modal}

Rasio keuntungan (provitability ratio) atau rentabilitas, yaitu rasio yang menunjukan kemampuan perusahaan untuk memperoleh keuntungan dari penggunaan modalnya (Harjito, D Agus dan Martono. (2011:53).

Menurut Sudana (2011:22) Menyatakan bahwa Profitability ratio mengukur kemampuan perusahaan untuk menghasilkan laba dengan menggunakan sumber-sumber yang dimiliki perusahaan, seperti aktiva, modal, atau penjualan perusahaan. Dengan demikian tingkat profitabilitas yang tinggi merupakan daya tarik bagi penanam modal di perusahaan.

Hal ini sesuai dengan penelitian yang dilakukan oleh Utami (2009), Pratheepkanth (2011), Najjar dan Krassimir Petrov (2011), Yuliati (2011), serta Sari dan A. Mulyo

Haryanto (2013). Berdasarkan uraian diatas dapat ditarik hipotesis sebagai berikut:

$\mathrm{H}_{2}$ : Profitabilitas berpengaruh terhadap struktur modal. 


\section{Pengaruh Likuiditas Terhadap Struktur Modal}

Likuiditas merupakan ukuran kinerja perusahaan dalam kemampuan perusahaan untuk memenuhi kewajiban keuangan yang segera harus dilunasi yaitu kewajiban yang jatuh temponya sampai dengan 1 tahun Sitanggang (2012:22).

Menurut pecking order theory, perusahaan yang mempunyai likuiditas yang tinggi akan cenderung tidak menggunakan pembiayaan dari hutang. Hal ini disebabkan perusahaan dengan likuiditas yang tinggi mempunyai dana internal yang besar, sehingga perusahaan tersebut akan lebih menggunakan dana internalnya terlebih dahulu untuk membiayai investasinya sebelum menggunakan pembiayaan eksternal melalui hutang (Sari dan A. Mulyo Haryanto, 2013).

Hal ini sesuai dengan penelitian yang dilakukan oleh Najjar dan Krassimir Petrov (2011), Yuliati (2011) serta Sari dan A. Mulyo Haryanto (2013). Berdasarkan uraian diatas dapat ditarik hipotesis sebagai berikut:

$\mathrm{H}_{3}$ : Likuiditas berpengaruh terhadap struktur modal.

\section{Pengaruh Struktur Aktiva Terhadap Struktur Modal \\ Menurut Sitanggang (2013:75),} struktur aktiva ialah perusahaan yang memiliki komposisi aktiva tetap berwujud yang jumlahnya besar, tentu akan mempunyai peluang untuk memperoleh tambahan modal dengan utang karena aktiva tetap tersebut dapat dijadikan sebagai agunan untuk memperoleh utang.
Menurut Brigham dan Houston (2011:188) Struktur asset, perusahaan yang asetnya memadai untuk digunakan sebagai jaminan pinjaman cenderung akan cukup banyak menggunakan utang. Asset umum yang dapat digunakan oleh banyak perusahaan dapat menjadi jaminan yang baik, sementara tidak untuk asset dengan tujuan khusus, jadi perusahaan real estate biasanya memiliki leverage yang tinggi sementara pada perusahaan yang terlibat dalam bidang penelitian teknologi, hal seperti ini tidak berlaku.

Dengan kata lain, dengan struktur aktiva yang besar berarti perusahaan memiliki rasio hutang yang besar (Sari dan A. Mulyo Haryanto, 2013). Perubahan struktur aktiva dapat mengakibatkan perubahan terhadap struktur modal, karena aktiva tetap bersumber dari utang jangka panjang.

Hal ini sesuai dengan penelitian yang dilakukan oleh Utami (2009), Najjar dan Krassimir Petrov (2011) serta Sari dan A. Mulyo Haryanto (2013). Berdasarkan uraian diatas dapat ditarik hipotesis sebagai berikut: $\mathrm{H}_{4}$ : Struktur Aktiva berpengaruh terhadap struktur modal

\section{Pengukuran dan Definisi Operasioal Variabel}

Definisi operasional diperlukan agar konsep yang digunakan dapat diukur serta menghindari terjadi kesalahan penafsiran yang berbeda.

a. Variabel Independen (X)

Variabel independen dapat disebut sebagai variabel yang mendahului, atau juga dapat dinamakan variabel yang diduga sebagai sebab 
terjadinya variabel dependen. Variabel independen penelitian ini adalah:

1) Profitabilitas $\left(X_{1}\right)$

Profitabilitas

adalah

Perbandingan antara jumlah laba yang tersedia bagi pemilik modal sendiri dengan jumlah modal sendiri yang menghasilkan laba. EAT

$R O E=\frac{(\text { Earning After Tax })}{\text { Total Equity }}$

2) Likuiditas $\left(X_{2}\right)$

Likuiditas yaitu Perbandingan antara harta lancar yang setara dengan kas ditambah sekuritas dengan utang lancar.

$$
\text { Rasio Kas }=\frac{\begin{array}{c}
\text { Kas + Setara Kas }+ \\
\text { Surat Berharga }
\end{array}}{\text { Utang }}
$$

3) Struktur Akiva $\left(X_{3}\right)$

Struktur Aktiva adalah Jumlah asset yang dapat dijadikan jaminan yang diukur dengan membandingkan antara aktiva tetap dan total aktiva.

Struktur Aktiva $=\frac{\mathrm{FA}}{\mathrm{TA}} \times 100 \%$

b. Variabel dependen (Y)

Variabel dependen yaitu variabel yang menjadi pusat perhatian penelitian, yang dijelaskan atau dipengaruhi oleh variabel independen. Variabel dependen dalam penelitian ini adalah Struktur Modal. Struktur Modal adalah perbandingan antara seluruh utang, termasuk utang lancar dengan seluruh ekuitas.

DER $=\frac{\text { Total Utang (debt) }}{\text { Ekuitas (equity) }}$
Metode Penelitian

Populasi dan Teknik Pengambilan Sampel

Populasi adalah keseluruhan objek atau subjek yang memenuhi kualitas dan karakteristik tertentu yang ditetapkan berkaitan dengan masalah penelitian. Populasi yang akan menjadi objek dalam penelitian ini adalah perusahaan manufaktur yang terdaftar di Bursa Efek Indonesia (BEI) pada tahun 2012 dan 2013. Teknik pengambilan sampel yang digunakan adalah mengunakan metode purposive sampling, yaitu teknik yang digunakan berdasarkan kriteria tertentu dan berdasarkan pertimbangan yang disesuaikan dengan tujuan penelitian. Sampel yang digunakan dalam penelitian ini berjumlah 50 perusahaan dari 137 perusahaan.

Dalam penelitian ini kriteria pemilihan sampel yang ditetapkan adalah sebagai berikut:

a. Perusahaan manufaktur yang terdaftar di Bursa Efek Indonesia (BEI) pada periode 2012 dan 2013.

b. Perusahaan menerbitkan laporan keuangan yang telah diaudit dan dinyatakan dalam rupiah ( $\mathrm{Rp})$ untuk periode 2012 dan 2013.

c. Data yang tersedia lengkap (data secara keseluruhan tersedia pada publikasi periode 31 Desember 2012 dan 31 Desember 2013) dan memiliki nilai ekuitas dan laba yang positif dalam laporan keuangan periode penelitian tahun 2012 dan 2013. 


\section{Model Regresi}

Regresi adalah suatu proses untuk memperkirakan secara sistematis tentang apa yang paling mungkin terjadi di masa yang akan datang berdasarkan informasi masa lalu dan sekarang yang dimiliki agar kesalahannya dapat diperkecil. Pembuktian terhadap hipotesis pada penelitian ini menggunakan model regresi berganda sebagai berikut :

$$
\mathrm{Y}=\mathrm{b} 0+\mathrm{b} 1 \mathrm{X}_{1}+\mathrm{b} 2 \mathrm{X}_{2}+\mathrm{b} 3 \mathrm{X}_{3}+\mathrm{e}
$$

Keterangan:

$$
\text { Y : Struktur modal }
$$$$
\text { b0 : Konstanta }
$$

b1, b2, b3 : Koefisien regresi untuk variabel independen

$\begin{array}{ll}\mathrm{X}_{1} & : \text { Profitabilitas } \\ \mathrm{X}_{2} & : \text { Likuiditas } \\ \mathrm{X}_{3} & : \text { Struktur Aktiva } \\ \mathrm{e} & : \text { Error Term }\end{array}$

\section{Hasil dan Pembahasan}

\section{Analisis Data dan Uji Hipotesis}

Analisis deskripsi dilakukan bertujuan untuk memberikan gambaran tentang distribusi frekuensi variabel-variabel independen yang digunakan dalam penelitian ini.
Penelitian ini menggunakan 3 variabel independen yang bertujuan untuk mengetahui pengaruh Profitabilitas, Likuiditas dan Struktur Aktiva terhadap variabel dependen Struktur Modal.

Penelitian ini menggunakan teknik analisis statistik deskriptif dan uji asumsi klasik untuk pengolahan data sedangkan untuk pengujian hipotesis menggunakan teknik analisis regresi berganda karena variabel independen (X) yang digunakan pada penelitian ini lebih dari 1 (satu).

Berdasarkan data olahan SPSS yang meliputi variabel independen Profitabilitas (ROE), Likuiditas (Rasio Kas) dan Struktur Aktiva, serta variabel dependen Struktur Modal (DER) maka dapat diketahui nilai maksimum, nilai minimum, rata-rata (mean) dan standar deviasi dari setiap variabel.

Berdasarkan hasil pengolahan data dengan menggunakan IBM SPSS (Statistical Product and Service Solutions) versi 21,0 diperolah perhitungan sebagai berikut:

\begin{tabular}{|l|c|r|r|r|r|}
\hline \multicolumn{5}{|c|}{ Descriptive Statistics } \\
Struktur Modal & $\mathbf{N}$ & Minimum & Maximum & Mean & Std. Deviation \\
Profitabilitas & 50 & .04 & 5.06 & 1.1485 & 1.03391 \\
Likuiditas & 50 & -3.74 & .32 & -1.9741 & .81313 \\
Struktur Aktiva & 50 & -5.61 & .53 & -1.7010 & 1.55521 \\
Valid N (listwise) & 50 & .09 & .68 & .4189 & .14124 \\
\hline
\end{tabular}

Dari hasil tabel statistik deskriptif diatas dapat diketahui bahwa:

a. Pada variabel struktur modal (Y) dengan 50 sampel perusahaan memiliki nilai minimum sebesar 0,04 , nilai maksimum sebesar 5,06, nilai rata-rata sebesar 1,1485 dan standar deviasi sebesar 1,03391.

b. Pada variabel profitabilitas (X1) dengan 50 sampel perusahaan memiliki nilai minimum sebesar 3,74 , nilai maksimum sebesar 0,32 , 
nilai rata-rata sebesar $-1,9741$ dan standar deviasi sebesar 0,81313 .

c. Pada variabel likuiditas (X2) dengan 50 sampel perusahaan memiliki nilai minimum sebesar $-5,61$, nilai maksimum sebesar 0,53 , nilai ratarata sebesar $-1,7010$ dan standar deviasi sebesar 1,55521.

d. Pada variabel struktur aktiva (X3) dengan 50 sampel perusahaan memiliki nilai minimum sebesar 0,09 , nilai maksimum sebesar 0,68 , nilai rata-rata sebesar 0,4189 dan standar deviasi sebesar 0,14124.

\section{Analisis Asumsi Klasik}

Untuk menguji kesalahan model regresi yang dilakukan dalam penelitian ini, maka harus dilakukan pengujian asumsi klasik. Pengujian asumsi klasik yang digunakan adalah uji multikolinearitas, autokorelasi, heteroskedastisitas dan normalitas yang secara rinci dapat dijelaskan sebagai berikut:

\section{Uji Multikolinearitas}

Uji multikolinieritas bertujuan untuk menguji apakah model regresi ditemukan adanya korelasi antar variabel independen, dimana model regresi yang baik seharusnya tidak terjadi korelasi antar variabel independen. Mengukur multikolinieritas dapat dilihat dari nilai toleransi atau VIF (Variance Inflation
Factor) dari masing-masing variabel. Berikut ini adalah hasil uji multikolinearitas terhadap struktur modal dalam tabel sebagai berikut:

Hasil Uji Multikolinearitas Coefficients $^{\mathrm{a}}$

\begin{tabular}{|l|l|r|r|}
\hline \multicolumn{2}{|l|}{ Model } & \multicolumn{2}{|c|}{$\begin{array}{c}\text { Collinearity } \\
\text { Statistics }\end{array}$} \\
\cline { 3 - 4 } \multicolumn{2}{|c|}{} & Tolerance & \multicolumn{1}{c|}{ VIF } \\
\hline \multirow{4}{*}{1} & (Constant) & & \\
\cline { 2 - 4 } & Profitabilitas & .900 & 1.112 \\
\cline { 2 - 4 } & Likuiditas & .887 & 1.128 \\
\cline { 2 - 4 } & Struktur Aktiva & .980 & 1.020 \\
\hline
\end{tabular}

a. Dependent Variable: Struktur Modal

Berdasarkan nilai Tolerance dan VIF diperoleh bahwa nilai tolerance berkisar antara 0,887 sampai 0,980, begitu juga dengan nilai VIF berkisar antara 1,020 sampai 1,128. Dengan demikian dalam model regresi penelitian ini tidak ditemukan adanya masalah multikolinearitas.

\section{Uji Autokorelasi}

Uji autokorelasi digunakan untuk mengetahui ada atau tidaknya korelasi yang terjadi antara kesalahan pengganggu pada periode tertentu dengan kesalahan pengganggu pada periode sebelumnya. Prasyarat yang harus terpenuhi adalah tidak adanya autokorelasi pada model regresi. Uji autokorelasi dilakukan melalui pengujian terhadap nilai Durbin-Watson (Uji DW).

\section{Hasil Uji Autokorelasi}

Model Summary ${ }^{\mathrm{b}}$

\begin{tabular}{|l|c|r|r|r|r|}
\hline Model & R & R Square & $\begin{array}{c}\text { Adjusted R } \\
\text { Square }\end{array}$ & $\begin{array}{l}\text { Std. Error of } \\
\text { the Estimate }\end{array}$ & $\begin{array}{r}\text { Durbin- } \\
\text { Watson }\end{array}$ \\
\hline 1 & $.550^{\mathrm{a}}$ & .302 & .257 & .89141 & 2.433 \\
\hline
\end{tabular}

a. Predictors: (Constant), Struktur Aktiva, Profitabilitas, Likuiditas

b. Dependent Variable: Struktur Modal 
Berdasarkan tabel 10 diketahui bahwa uji autokorelasi dengan $\mathrm{k}=3$ $\mathrm{n}=50$ memiliki $\mathrm{dL}=1,421, \mathrm{dU}=1,674$ dan nilai Durbin Watson (DW) sebesar 2,433. Oleh karena nilai Durbin-Watson 2.433 terletak $(4-\mathrm{du}=2,326)$ dan $(4-$ $\mathrm{dl}=2,579)$, menunjukkan bahwa Durbin-Watson berada di daerah tidak ada autokorelasi. Sehingga data yang digunakan dalam penelitian ini bebas dari autokorelasi.

\section{Uji Heteroskedastisitas}

Uji Heteroskedastisitas digunakan untuk mengetahui ada atau tidaknya ketidaksamaan varian dari residual pada model regresi. Prasyarat yang harus terpenuhi dalam model regresi adalah tidak heteroskedastisitas. Untuk menentukan heterokedastisitas dapat melihat grafik scatterplot. Hasil uji heterokedastisitas dengan menggunakan grafik scatterplot di tunjukkan gambar di bawah ini:

\section{Hasil Grafik Scatterplot Uji Heteroskedastisitas}

Grafik scatterplot di atas, terlihat bahwa titik-titik menyebar secara acak, baik di atas maupun di bawah angka 0 pada sumbu Y. Hal ini dapat disimpulkan bahwa tidak terjadi masalah heterokedastisitas pada model regresi yang digunakan penelitian ini.

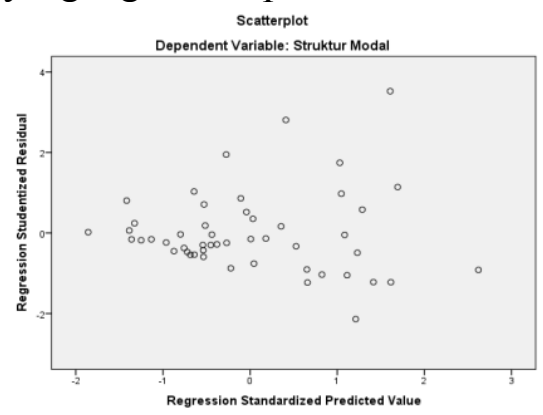

\section{Uji Normalitas}

Uji Normalitas digunakan pada analisis statistik non parametrik, asumsi yang harus dimiliki oleh data, data tersebut harus terdistribusi secara normal, Uji Normalitas dilakukan dengan melakukan pembuatan grafik normal probability plot. Jika data menyebar disekitar garis diagonal dan mengikuti arah garis diagonal, maka model regresi tersebut memenuhi asumsi normalitas. Sebaliknya jika data menyebar jauh dari garis diagonal atau tidak mengikuti arah garis diagonal, maka model regresi tersebut tidak memenuhi asumsi normalitas.

Berdasarkan hasil pengolahan data dengan bantuan IBM SPSS (Statistical Product and Service Solution) 21.0 diperoleh hasil sebagai berikut:

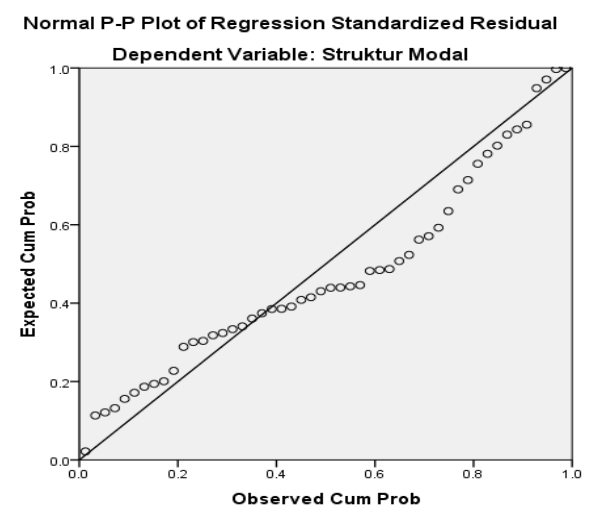

\section{Hasil Grafik Normal Probability Plot Uji Normalitas}

Berdasarkan gambar 3 dapat terlihat titik-titik yang menyebar di sekitar garis diagonal, serta penyebarannya mengikuti arah garis diagonal, maka model regresi ini layak dipakai karena data tersebut berdistribusi normal dan memenuhi uji normalitas. Uji Normalitas dalam penelitian ini juga menggunakan 
Kolmogorov-Smirnov. Dasar pengambilan keputusan adalah melihat angka probabilitas, dengan ketentuan : Probabilitas $>0,05$ : Hipotesis diterima karena data berdistribusi secara normal.
Probabilitas $<0,05$ : Hipotesis ditolak karena data tidak berdistribusi secara normal

\section{Hasil Uji Normalitas}

\begin{tabular}{|c|c|c|c|c|c|c|}
\hline \multicolumn{7}{|c|}{ One-Sample Kolmogorov-Smirnov Test } \\
\hline & & $\begin{array}{l}\text { Struktur } \\
\text { Modal }\end{array}$ & Profitabilitas & Likuiditas & $\begin{array}{l}\text { Struktur } \\
\text { Aktiva }\end{array}$ & $\begin{array}{c}\text { Unstandardized } \\
\text { Residual }\end{array}$ \\
\hline \multicolumn{2}{|l|}{$\mathrm{N}$} & 50 & 50 & 50 & 50 & 50 \\
\hline \multirow{2}{*}{$\begin{array}{l}\text { Normal } \\
\text { Parameters }\end{array}$} & Mean & 1,1485 & 1943 & ,4513 & 4189 &, 0000000 \\
\hline & $\begin{array}{l}\text { Std. } \\
\text { Deviation }\end{array}$ & 1,03391 & ,21139 & ,53514 & , 14124 & ,85699072 \\
\hline \multirow{3}{*}{$\begin{array}{l}\text { Most Extreme } \\
\text { Differences }\end{array}$} & Absolute &, 184 & ,258 & 238 &, 098 &, 129 \\
\hline & Positive &, 184 & 258 & 238 & ,097 & ,129 \\
\hline & Negative &,- 150 &,- 210 &,- 201 &,- 098 &,- 076 \\
\hline \multicolumn{2}{|c|}{ Kolmogorov-Smirnov Z } & 1,299 & 1,824 & 1,685 & ,696 & ,914 \\
\hline \multicolumn{2}{|c|}{ Asymp. Sig. (2-tailed) } &, 069 &, 003 &, 007 & ,718 & ,374 \\
\hline
\end{tabular}

a. Test distribution is Normal.

b. Calculated from data.

Setelah hasil tersebut di uji dengan Logaritma Natural (Ln) maka didapat hasil uji Normalitas dibawah ini:

\section{Hasil Uji Normalitas}

\begin{tabular}{|c|c|c|c|c|c|c|}
\hline \multicolumn{7}{|c|}{ One-Sample Kolmogorov-Smirnov Test } \\
\hline & & $\begin{array}{l}\text { Struktur } \\
\text { Modal }\end{array}$ & Profitabilitas & Likuiditas & $\begin{array}{l}\text { Struktur } \\
\text { Aktiva }\end{array}$ & $\begin{array}{c}\text { Unstandardized } \\
\text { Residual } \\
\end{array}$ \\
\hline \multicolumn{2}{|l|}{$\mathrm{N}$} & 50 & 50 & 50 & 50 & 50 \\
\hline \multirow[b]{2}{*}{$\begin{array}{l}\text { Normal } \\
\text { Parameters }{ }^{\mathrm{a}, \mathrm{b}}\end{array}$} & Mean & 1,1485 & $-1,9741$ & $-1,7010$ & ,4189 &, 0000000 \\
\hline & $\begin{array}{l}\text { Std. } \\
\text { Deviation }\end{array}$ & 1,03391 & ,81313 & 1,55521 &, 14124 & ,86368783 \\
\hline \multirow{3}{*}{$\begin{array}{l}\text { Most Extreme } \\
\text { Differences }\end{array}$} & Absolute &, 184 & 105 &, 088 & ,098 & ,156 \\
\hline & Positive &, 184 &, 105 &, 076 & ,097 &, 156 \\
\hline & Negative &,- 150 &,- 097 &,- 088 &,- 098 &,- 086 \\
\hline \multicolumn{2}{|c|}{ Kolmogorov-Smirnov Z } & 1,299 &, 744 &, 624 &, 696 & 1,104 \\
\hline \multicolumn{2}{|c|}{ Asymp. Sig. (2-tailed) } &, 069 & ,637 & ,831 & ,718 &, 175 \\
\hline
\end{tabular}

a. Test distribution is Normal.

b. Calculated from data.

\section{Uji Hipotesis}

Uji F

Uji $F$ digunakan untuk menguji signifikansi secara menyeluruh atas variabel independen (Profitabilitas, Likuiditas dan Struktur Aktiva) secara simultan berpengaruh terhadap variabel dependen (Struktur Modal). Berikut ini adalah output SPSS uji F sebagai berikut: 
Hasil Uji Hipotesis Secara Simultan

\begin{tabular}{|l|l|r|r|r|c|c|}
\hline \multicolumn{7}{|c|}{ ANOVA $^{\mathbf{a}}$} \\
\hline \multicolumn{2}{|l|}{ Model } & Sum of Squares & \multicolumn{1}{c|}{ Df } & Mean Square & F & Sig. \\
\hline \multirow{3}{*}{1} & Regression & 15.827 & 3 & 5.276 & 6.639 & $.001^{\mathrm{b}}$ \\
\cline { 2 - 7 } & Residual & 36.552 & 46 & .795 & & \\
\cline { 2 - 7 } & Total & 52.379 & 49 & & & \\
\hline
\end{tabular}

a. Dependent Variable: Struktur Modal

b. Predictors: (Constant), Struktur Aktiva, Profitabilitas, Likuiditas

Berdasarkan tabel diatas uji $\mathrm{F}$, menunjukan bahwa nilai $\mathrm{F}_{\text {hitung }}$ sebesar 6,639 dengan signifikansi 0,001 . Sedangkan untuk mencari $\mathrm{F}_{\text {tabel }}$ dengan jumlah sampel $(\mathrm{n})=50$; jumlah variabel independent $(\mathrm{K})=3$; taraf signifikansi $(\dot{\alpha})=0,05$, dengan $\mathrm{df}$ pembilang $=$ jumlah variabel $-1=4-$ $1=3$ dan df penyebut $=$ jumlah data jumlah variabel $=50-4=46$, maka $\mathrm{df}$ total $=\mathrm{df}$ pembilang $+\mathrm{df}$ penyebut $=3+46=49$ dengan menggunakan tabel distribusi $\mathrm{F}$ dan taraf signifikansi 0,05 diperoleh nilai $F_{\text {tabel }}$ sebesar 2,794. Diketahui $F_{\text {hitung sebesar 6,639 }}$ sedangkan $F_{\text {tabel }}$ sebesar 2,794, maka $\mathrm{F}_{\text {hitung }}>\mathrm{F}_{\text {tabel }}$ dengan tingkat signifikansi $0,001<0,05$. Berdasarkan tabel diatas dapat diketahui $F_{\text {hitung }}$ sebesar 6,639 dan nilai $F_{\text {tabel }}$ sebesar
2,794 hal tersebut menunjukkan bahwa $F_{\text {hitung }}>F_{\text {tabel, }}$, dengan tingkat signifikansi $0,001<0,05$. Dengan demikian $\mathrm{H}_{0}$ ditolak dan $\mathrm{H}_{\mathrm{a}}$ diterima, artinya terdapat pengaruh dari variabel independent yaitu Profitabilitas, Likuiditas dan Struktur Aktiva secara simultan terhadap variabel dependent Struktur Modal.

$\mathbf{R}^{2}$

Koefisien determinasi berfungsi untuk melihat seberapa besar variabel independen yaitu Profitabilitas, Likuiditas dan Struktur Aktiva bisa menjelaskan variabel dependen Struktur Modal. Besarnya nilai koefisien determinasi dapat dijelaskan pada tabel sebagai berikut:

\section{Hasil Uji Koefisien Determinasi}

\begin{tabular}{|c|c|c|c|}
\hline \multicolumn{4}{|c|}{ Model Summary $^{\mathbf{b}}$} \\
\hline Model & $\mathrm{R}$ & R Square & $\begin{array}{c}\text { Adjusted } \\
\text { R Square }\end{array}$ \\
\hline 1 & $.550^{\mathrm{a}}$ & .302 & .257 \\
\hline
\end{tabular}
a. Predictors: (Constant), Struktur
Aktiva,Profitabilitas, Likuiditas
b. Dependent Variable: Struktur Modal

\section{Uji t}

Uji $t$ dimaksudkan untuk mengetahui apakah terdapat pengaruh secara parsial (individu) dari variabelvariabel independen yaitu Profitabilitas, Likuiditas dan Struktur yaitu: 
Hasil Uji Hipotesis Secara Parsial

\begin{tabular}{|c|c|c|c|c|c|c|}
\hline \multicolumn{7}{|c|}{ Coefficients $^{\mathrm{a}}$} \\
\hline \multirow{2}{*}{\multicolumn{2}{|c|}{ Model }} & \multicolumn{2}{|c|}{$\begin{array}{l}\text { Unstandardized } \\
\text { Coefficients }\end{array}$} & \multirow{2}{*}{$\begin{array}{c}\begin{array}{c}\text { Standardized } \\
\text { Coefficients }\end{array} \\
\text { Beta } \\
\end{array}$} & \multirow[t]{2}{*}{$\mathbf{T}$} & \multirow[t]{2}{*}{ Sig. } \\
\hline & & $\mathrm{B}$ & Std. Error & & & \\
\hline \multirow{4}{*}{1} & (Constant) & 1.260 & .529 & & 2.381 & .021 \\
\hline & Profitabilitas & .004 & .165 & .003 & .027 & .979 \\
\hline & Likuiditas & -.320 & .087 & -.481 & -3.675 & .001 \\
\hline & Struktur Aktiva & -1.543 & .911 & -.211 & -1.694 & .097 \\
\hline
\end{tabular}

a. Dependent Variable: Struktur Modal

Hasil pengujian untuk Profitabilitas diperoleh nilai $t_{\text {hitung }}$ sebesar 0,027 . Nilai $t_{\text {tabel }}$ dengan $\mathrm{df}=\mathrm{n}$ - k- 1 yaitu $50-3-1=46$ dengan alfa 0,05 . Maka $t_{\text {tabel }}$ sebesar 1,679 nilai $t_{\text {hitung }} 0,027<t_{\text {tabel }} 1,679$. Tingkat signifikansi menunjukan angka 0.979 dengan taraf signifikansi sebesar 0.05, yang artinya lebih besar dari 0,05 $(0,979>0,05)$ maka Ho diterima dan Ha ditolak. Dengan demikian maka tidak terdapat pengaruh yang signifikan antara Profitabilitas terhadap Struktur Modal.

Hasil pengujian untuk Likuiditas diperoleh nilai thitung sebesar 3,675. Nilai $\mathrm{t}_{\text {tabel }}$ dengan $\mathrm{df}=\mathrm{n}-\mathrm{k}-1$ yaitu $50-3-1=46$ dengan alfa 0,05 . Maka $t_{\text {tabel }}$ sebesar 1,679 nilai $t_{\text {hitung }} 3,675>$ $t_{\text {tabel }}$ 1,679. Tingkat signifikansi menunjukan angka 0.000 dengan taraf signifikansi sebesar 0.05 , yang artinya lebih kecil dari $0,05(0,001<0,05)$ maka Ho ditolak dan Ha diterima. Dengan demikian maka terdapat pengaruh yang signifikan antara Likuiditas terhadap Struktur Modal.

Hasil pengujian untuk Struktur Aktiva diperoleh nilai $t_{\text {hitung }}$ sebesar 1,694. Nilai $\mathrm{t}_{\text {tabel }}$ dengan $\mathrm{df}=\mathrm{n}-\mathrm{k}-1$ yaitu $50-3-1=46$ dengan alfa 0,05 . Maka $t_{\text {tabel }}$ sebesar 1,679 nilai $t_{\text {hitung }}$ $1,694>t_{\text {tabel }} 1,679$. Tingkat signifikansi menunjukan angka 0.097 dengan taraf signifikansi sebesar 0.05 , yang artinya lebih besar dari 0,05 $(0,097>0,05)$ maka Ho diterima dan Ha ditolak. Dengan demikian maka tidak terdapat pengaruh yang signifikan antara Struktur Aktiva terhadap Struktur Modal.

\section{Pembahasan}

Analisis besarnya Profitabilitas, Likuiditas dan Struktur Aktiva pada perusahaan manufaktur yang terdaftar di Bursa Efek Indonesia (BEI) pada tahun 2012 dan 2013 menggunakan SPSS diperoleh hasil bahwa besarnya tingkat Profitabilitas, Likuiditas dan Struktur Aktiva perusahaan yang menjadi objek penelitian, secara simultan mempunyai pengaruh yang signifikan terhadap Struktur Modal, maka hipotesis $1\left(\mathrm{H}_{1}\right)$ diterima. Hasil penelitian ini konsisten dengan penelitian yang dilakukan oleh Sari dan A. Mulyo Haryanto (2013). Hasil koefisien determinasi (Adjusted $\mathrm{R}^{2}$ ) dari ketiga variabel tersebut yaitu Profitabilitas, Likuiditas dan Struktur Aktiva dapat menjelaskan struktur modal hanya sebesar $25,7 \%$. Hal ini dapat disimpulkan bahwa variabel Struktur Modal dapat dijelaskan oleh 
variabel Profitabilitas, Likuiditas dan Struktur Aktiva.

Pengujian hipotesis untuk variabel Profitabilitas menunjukkan nilai signifikan $0,979>0,05$ sehingga dapat disimpulkan bahwa Profitabilitas tidak memiliki pengaruh terhadap Struktur Modal, maka hipotesis $2\left(\mathrm{H}_{2}\right)$ ditolak. Hasil ini sejalan dengan penelitian yang dilakukan oleh Seftianne dan Ratih Handayani (2011). Hasil pengujian ini menyatakan bahwa perusahaan yang mengalami kesulitan keuangan akan meminjam uang atau mengeluarkan saham dengan kondisi tertentu agar mendapatkan sumber dana untuk kegiatan operasionalnya

Pengujian hipotesis untuk variabel Likuiditas menunjukan nilai signifikan $0,001<0,05$ sehingga dapat disimpulkan bahwa Likuiditas memiliki pengaruh terhadap Struktur Modal, maka hipotesis $3 \quad\left(\mathrm{H}_{3}\right)$ diterima. Hasil ini sejalan dengan penelitian yang dilakukan oleh Najjar dan Krassimir Petrov (2011), Yuliati (2011) serta Sari dan A. Mulyo Haryanto (2013). Berdasarkan pecking order theory, dapat disimpulkan bahwa perusahaan yang mempunyai likuiditas yang tinggi akan cenderung tidak menggunakan pembiayaan dari hutang. Hal ini disebabkan perusahaan dengan likuiditas yang tinggi mempunyai dana internal yang besar, sehingga perusahaan tersebut akan lebih menggunakan dana internalnya terlebih dahulu untuk membiayai investasinya sebelum menggunakan pembiayaan eksternal melalui hutang.

Pengujian hipotesis untuk variabel Struktur Aktiva menunjukan nilai signifikan $0,097>0,05$ sehingga dapat disimpulkan bahwa Struktur Aktiva tidak memiliki pengaruh terhadap Struktur Modal, maka hipotesis $4\left(\mathrm{H}_{4}\right)$ ditolak. Hasil ini sejalan dengan penelitian yang dilakukan oleh Seftianne dan Ratih Handayani (2011) dan Sri Yuliati (2011). Hasil pengujian ini menyatakan bahwa semakin tinggi struktur aktiva maka struktur modal semakin rendah. Begitupun sebaliknya, semakin rendah struktur aktiva maka akan semakin tinggi struktur modal. Perusahaan yang memiliki aktiva yang lebih besar, akan lebih mudah dalam memperoleh pinjaman jangka panjang. Oleh karena itu, pendanaan perusahaan akan dilakukan dengan perolehan pinjaman jangka panjang.

\section{Kesimpulan, Keterbatasan dan Kontribusi Praktis \\ Simpulan}

Tujuan penelitian ini adalah untuk menguji dan membuktikan secara empiris pengaruh Profitabilitas, Likuiditas dan Struktur Aktiva terhadap Struktur Modal pada periode 2012 dan 2013, dengan sampel yang digunakan dalam penelitian ini adalah 50 (Lima Puluh) perusahaan manufaktur yang terdaftar di Bursa Efek Indonesia (BEI).

Berdasarkan analisis dan hasil pembahasan yang sebelumnya telah diuraikan pada bab-bab sebelumnya serta pengujian yang telah dilakukan maka dapat diambil kesimpulan sebagai berikut:

a. Berdasarkan Uji Simultan, menunjukkan bahwa Profitabilitas, Likuiditas dan Struktur Aktiva berpengaruh 
signifikan terhadap Struktur Modal.

b. Berdasarkan Uji Parsial, hanya variabel Likuiditas yang berpengaruh signifikan terhadap Struktur Modal. Sedangkan variabel Profitabilitas dan Struktur Aktiva tidak berpengaruh signifikan terhadap Struktur Modal.

c. Berdasarkan Uji Koefisien determinasi (R2), ketiga variabel tersebut yaitu Profitabilitas, Likuiditas dan Struktur Aktiva dapat menjelaskan struktur modal hanya sebesar 25,7\%. Hal ini dapat disimpulkan bahwa variasi Struktur Modal dapat dijelaskan oleh variabel Profitabilitas, Likuiditas dan Struktur Aktiva. Sedangkan sisanya sebesar $100 \%$ $-25,7 \%=74,3 \%$ dipengaruhi atau dijelaskan oleh variabel lain yang tidak dimasukan dalam model penelitian ini.

\section{Keterbatasan}

Penelitian ini secara garis besar mempunyai keterbatasan antara lain waktu yang terbatas dan akan labih menyeluruh apabila penelitian dilakukan dengan sampel seluruh perusahaan yang terdaftar dalam Bursa Efek Indonesia.

\section{Kontribusi Praktis}

a. Bagi Perusahaan

Sebagai salah satu bahan pertimbangan dan informasi bagi manajer keuangan dalam hal pengambilan keputusan keuangan untuk menentukan struktur modal yang optimal pada perusahaan manufaktur yang terdaftar di Bursa Efek Indonesia.

b. Bagi Investor dan Masyarakat

Memberi gambaran mengenai analisa struktur modal pada perusahaan manufaktur serta faktor-faktor mempengaruhinya, sehingga investor maupun masyarakat dapat membuat keputusan investasi dan keputusan pendanaan yang tepat

\section{DAFTAR PUSTAKA}

Brigham, F Eugene dan Joel F Houston. (2011). Dasar-dasar Manajemen Keuangan. Edisi kesebelas. Buku dua. Jakarta: Salemba Empat.

Bursa Efek Indonesia. Factbook. diakses pada pukul 16.58 WIB pada tanggal 16 Desember 2013. www.idx.co.id.

/publikasi/factbook.aspx/

Bursa Efek Indonesia. Laporan Keuangan. diakses pada pukul 14.48 WIB pada tanggal 10 Juni 2014. www.idx.co.id.

Ghozali, Imam. 2011. Aplikasi Analisis Multivariate dengan Program SPSS. Semarang: Badan Penerbit Universitas Dipenogoro.

Harjito, D Agus dan Martono. (2011). Manajemen Keuangan. Edisi kedua. Cetakan pertama. Yogyakarta: Ekonisia.

Kasmir. (2012). Analisis Laporan Keuangan. Edisi pertama. Cetakan kelima. Jakarta: PT Raja Grafindo Persada.

Manururng, Adler Haymans. (2012).

Teori Keuangan Perusahaan. Cetakan pertama. Jakarta: PT Adler Manurung Press. 
Najjar dan Krassimir Petrov (2011).

Capital Structure of Insurance Companies in Bahrain". ISSN 1833-3850, E-ISSN 1833-8119. International Journal of Business and Management. Volume. 6, No. 11.

Pratheepkanth, Puwanenthiren.

(2011). Capital Structure and Financial Performance.

Evidence From Selected

Business Companies In

Colombo Stock Excange Sri

Langka. E-ISSN 2229-4686

ISSN 2231-4172. Journal of Arts, Science \& Commerce.

Priyatno, Duwi. (2013). Analisis Korelasi, Regresi, dan Multivariate dengan SPSS. Buku pertama. Yogyakarta: GAVA MEDIA.

Santoso, Singgih. (2013). Menguasai SPSS 21 di Era Informasi. Jakarta: PT Elex Media Komputindo Kelompok Gramedia.

Sari, Devi Verena dan A. Mulyo Haryanto (2013). Pengaruh Profitabilitas, Pertumbuhan Aset, Ukuran Perusahaan, Struktur Aktiva dan Likuiditas Terhadap Struktur Modal Pada Perusahaan Manufaktur di Bursa Efek Indonesia Tahun 20082010 Diponegoro Journal of Management. Volume. 2, No. 3. Sarjono dan Winda Julianita. (2011). SPSS vS LISREL: Sebuah Pengantar, Aplikasi untuk Riset. Jakarta: Salemba Empat

Seftianne dan Ratih Handayani. (2011). Faktor-Faktor yang Mempengaruhi Struktur Modal pada Perusahaan Publik Sektor Manufaktur. Jurnal Bisnis dan Akuntansi. Volume.13, No. 1; hal $39-56$.

Sitanggang, Dr. J. P. (2012). Manajemen Keuangan Perusahaan, Dilengkapi soal dan Penyelesaian. Jakarta: Mitra Wacana Media.

Sitanggang, Dr. J. P. (2013). Manajemen Keuangan Perusahaan Lanjutan. Edisi pertama. Jakarta: Mitra Wacana Media.

Sudana, I Made. (2011). Manajemen Keuangan Perusahaan Teori dan Praktik. Jakarta: Erlangga.

Tabel Durbin-Watson (DW), $\alpha=5 \%$. diakses pada pukul 15.45 WIB pada tanggal 20 Juli 2014. www.junaidichaniago.wordpress .com/

Utami, Endang Sri. (2009). Faktorfaktor Yang Mempengaruhi Struktur Modal Perusahaan Manufaktur. ISSN 1693-4296. FENOMENA. Volume. 7, No. 1; hal 39-47.

Yuliati, Sri. (2011). Pengujian Pecking Order Theory : Analisis FaktorFaktor yang Mempengaruhi Struktur Modal Industri Manufaktur di BEI Periode Setelah Krisis Moneter. Politeknosains. Volume. X, No.1. 